\title{
Identification of a novel HLA-A24-restricted cytotoxic $T$ Iymphocyte epitope peptide derived from mesothelin in pancreatic cancer
}

\author{
Mariko Tsukagoshi ${ }^{1,2}$, Satoshi Wada $^{3,4}$, Seiko Hirono ${ }^{5}$, Shintaro Yoshida ${ }^{4}$, Erica \\ Yada $^{4}$, Tetsuro Sasada ${ }^{4}$ Ken Shirabe ${ }^{1,3}$, Hiroyuki Kuwano ${ }^{3}$ and Hiroki Yamaue ${ }^{5}$ \\ ${ }^{1}$ Division of Hepatobiliary and Pancreatic Surgery, Department of General Surgical Science, Gunma University Graduate \\ School of Medicine, Maebashi Gunma 371-8511, Japan \\ ${ }^{2}$ Department of Innovative Cancer Immunotherapy, Gunma University Graduate School of Medicine, Maebashi Gunma \\ 371-8511, Japan \\ ${ }^{3}$ Department of General Surgical Science, Gunma University Graduate School of Medicine, Maebashi Gunma 371-8511, \\ Japan \\ ${ }^{4}$ Department of Cancer Immunotherapy, Kanagawa Cancer Center, Asahi-ku, Yokohama Kanagawa 241-8515, Japan \\ ${ }^{5}$ Second Department of Surgery, Wakayama Medical University, Wakayama 641-8510, Japan \\ Correspondence to: Hiroki Yamave, email: yamave-h@wakayama-med.ac.jp \\ Keywords: mesothelin; epitope peptide; cancer vaccine; immunotherapy; pancreatic cancer
}

Received: January 16, $2018 \quad$ Accepted: July 12, $2018 \quad$ Published: July 31, 2018

Copyright: Tsukagoshi et al. This is an open-access article distributed under the terms of the Creative Commons Attribution License 3.0 (CC BY 3.0), which permits unrestricted use, distribution, and reproduction in any medium, provided the original author and source are credited.

\section{ABSTRACT}

Pancreatic cancer involves highly malignant tumors, and the development of new therapeutic strategies is critical. Mesothelin is overexpressed in infiltrating pancreatic cancer cells and plays an important role in the invasion and migration processes. In this study, we focused on mesothelin as a tumor-specific antigen target for a pancreatic cancer vaccine. We first investigated the mesothelin-derived epitope peptide restricted to HLA-A*2402. A total of 19 candidate peptides were synthesized, and we then determined their potential to induce peptide-specific cytotoxic T lymphocytes (CTLs). Peptide-specific CTLs were induced by five peptides derived from mesothelin, and these CTLs successfully exhibited peptide-specific IFN-Y production. After the expansion of each CTL, two CTL lines were established, which were induced by mesothelin-10-5 peptide (AFYPGYLCSL). These CTL lines exhibited peptide-specific cytotoxicity and IFN-Y production. Moreover, we were able to generate mesothelin-10-5 peptide-specific CTL clones. These CTL clones also had specific cytotoxic activity against HLA-A*2402-positive pancreatic cancer cells that endogenously expressed mesothelin. These results indicate that the mesothelin-10-5 peptide is a novel HLA-A*2402 restricted CTL epitope and that it is a promising candidate target for antigen-specific immunotherapy against pancreatic cancers.

\section{INTRODUCTION}

Pancreatic cancer is one of the most lethal malignancies and is associated with poor prognosis, and the 5 -year relative survival rate is currently $8 \%$ [1]. This low rate is partly due to the fact that more than one-half of cases are diagnosed at a late stage, and therapeutic modalities are very limited $[1,2]$. Although surgical resection is the only curative treatment for pancreatic cancer, even the 5-year survival rate after a curative resection is only $20 \%$ [3]. Therefore, the identification of novel therapeutic modalities is critical for improving patient prognosis.

Recently, the development of cancer immunotherapy has considerably expanded. In particular, immune checkpoint inhibitors such as anti-cytotoxic T-lymphocyte antigen 4 (CTLA-4), anti-programmed death 1 (PD-1), and anti-programmed death ligand 1 (PD-L1) antibodies represent significant recent developments. Although 
immune checkpoint inhibitors have successfully achieved durable antitumor responses in a variety of malignant diseases, only a fraction of patients respond to treatment, and objective response rates have ranged from approximately $10 \%$ to $30 \%$ in clinical trials $[4,5]$. Moreover, immune checkpoint inhibitors have been shown to be ineffective as single agents in the treatment of pancreatic cancer and to not prolong survival $[6,7]$. Hence, combined therapeutic approaches are necessary to achieve complete tumor regression and are being evaluated [8]. A recent study reported that immune checkpoint inhibitors combined with a cancer vaccine may alter the microenvironment from a cold tumor to a hot tumor and enhance the vaccine-induced anti-tumor response [9]. Therefore, we explored potential targets for combination therapy with immune checkpoint inhibitors in pancreatic cancer.

Pancreatic cancer is aggressive and characterized by invasiveness, rapid progression, and profound resistance to treatment [10]. The invasion and metastasis processes are crucial to the pathogenesis of pancreatic cancer; however, their genetic and biochemical determinants are still not fully understood [11]. We previously identified specific genes, MUC16 and mesothelin, associated with invasion and migration processes in pancreatic cancer [12]. We reported that MUC16 and mesothelin were overexpressed only in infiltrating pancreatic cancer cells but not in PanIN-3 cells or normal pancreatic tissues. It has also been reported that mesothelin may play an important role in cell adhesion [13], cell proliferation and migration, tumor progression $[14,15]$, and resistance to chemotherapy [16]. Thus, mesothelin might be an attractive target for the development of novel cancer treatments for pancreatic cancer.

In the present study, we focused on mesothelin as a novel tumor-specific antigen target for anticancer immunotherapy for pancreatic cancer. We investigated the mesothelin-derived epitope peptide restricted to HLA-A 2402 that can induce peptide-specific cytotoxic T lymphocytes (CTLs) for possible use in peptide-based immunotherapies for patients with HLA-A* 2402-positive pancreatic cancer.

\section{RESULTS}

\section{CTL responses to candidate peptides derived from mesothelin}

To identify mesothelin-derived and HLA-A24restricted CTL epitopes, we synthesized a total of 19 candidate 9-mer and 10-mer peptides that were expected to have high binding affinity to HLA-A24 using the BIMAS program (Table 1). These peptides were evaluated for their potential to induce peptide-specific CTLs in vitro from human PBMCs obtained from HLA-A24 healthy donors (Figure 1). CTLs were induced by a three-time stimulation with DCs loaded with mesothelin-derived peptides. Then, CTLs were examined for specificity for each peptide using IFN- $\gamma$ ELISPOT assays. Peptide-specific CTLs were judged to have been successfully induced when there were more than 100 spot counts for each and 30 more spot counts than the control. Five peptides could induce peptide-specific CTLs that produced IFN- $\gamma$ and were able to specifically recognize T2-A24 cells pulsed with each peptide but not T2-A24 cells not pulsed with peptides (Figure 2A).

\section{Establishment of CTL lines that respond to epitope peptides derived from mesothelin}

After CTL-expanding culture, only the mesothelin-10-5 peptide-specific CTLs produced a large amount of IFN- $\gamma$ in ELISPOT assays (Figure 2B). CTL activity was also examined by IFN- $\gamma$ ELISA. The mesothelin-10-5 peptide-specific CTLs produced a large amount of IFN- $\gamma$ specifically in response to T2A24 cells pulsed with the mesothelin-10-5 peptide but not to T2A24 cells with HIV peptide loading (Figure 2C). Similarly, in independent experiments using PBMCs from two other healthy donors, mesothelin-10-5 peptide could induce CTLs that produced high levels of IFN- $\gamma$ (data not shown).

The cytotoxic activity of the mesothelin-10-5 peptide-specific CTLs was examined using a fluorescencebased cytotoxicity assay. The mesothelin-10-5 peptidespecific CTLs demonstrated cytotoxic activity against T2A24 cells pulsed with the mesothelin-10-5 peptide but not against T2A24 cells with HIV peptide loading (Figure 2D).

\section{Establishment of mesothelin-derived peptide- specific CTL clones}

We next extracted CTL clones from the CTL lines and finally established four CTL clones using a limiting dilution method using CTL lines that responded to mesothelin-10-5 peptide (Figure 3A). The established mesothelin-10-5 peptide-specific CTL clones produced a high level of IFN- $\gamma$ specifically in response to mesothelin10-5-pulsed T2A24 cells, whereas no IFN- $\gamma$ production was detected against T2A24 cells not pulsed with the peptide, even after CTL clone expansion (Figure 3B).

\section{Peptide-specific CTL response to mesothelin and HLA-A 2402-expressing pancreatic cancer cells}

The responses of the established mesothelin-10-5 peptide-specific CTL clones were examined. The pancreatic cancer cell lines KP2, KP3, ASPC1, and SUIT2 expressed mesothelin, whereas PANC1 and KP4 did not. Furthermore, the KP2, KP3, KP4, and SUIT2 cell lines expressed HLA-A ${ }^{*} 2402$, whereas ASPC1 and PANC1 cells did not (Table 2 and Figure 4A). The mesothelin-10-5 peptide- 
Table 1: Candidate peptides derived from mesothelin restricted with HLA-A*24:02

\begin{tabular}{|c|c|c|c|}
\hline Peptide name & Position & Amino acid sequence (mer) & Binding score \\
\hline meso-9-1 & $443-451$ & FYPGYLCSL (9) & 300 \\
\hline meso-9-2 & $483-491$ & LYPKARLAF (9) & 150 \\
\hline meso-9-3 & $498-506$ & EYFVKIQSF (9) & 120 \\
\hline meso-9-4 & $424-432$ & RFVKGRGQL (9) & 60 \\
\hline meso-9-5 & $592-600$ & GYLVLDLSM (9) & 45 \\
\hline meso-9-6 & $499-507$ & YFVKIQSFL (9) & 42 \\
\hline meso-9-7 & $413-421$ & RPLPQVATL (9) & 14.4 \\
\hline meso-9-8 & $306-314$ & KAREIDESL (9) & 13.4 \\
\hline meso-9-9 & $206-214$ & RLVSCPGPL (9) & 12 \\
\hline meso-9-10 & $429-437$ & RGQLDKDTL (9) & 12 \\
\hline meso-10-1 & $362-371$ & GYPESVIQHL (10) & 604.8 \\
\hline meso-10-2 & $498-507$ & EYFVKIQSFL (10) & 280 \\
\hline meso-10-3 & $194-203$ & RFVAESAEVL (10) & 60 \\
\hline meso-10-4 & $67-76$ & GFPCAEVSGL (10) & 30 \\
\hline meso-10-5 & $442-451$ & AFYPGYLCSL (10) & 24 \\
\hline meso-10-6 & $182-191$ & RALGGLACDL (10) & 14.4 \\
\hline meso-10-7 & $91-100$ & KNVKLSTEQL (10) & 12 \\
\hline meso-10-8 & $385-394$ & KWNVTSLETL (10) & 12 \\
\hline meso-10-9 & $548-557$ & KLLGPHVEGL (10) & 12 \\
\hline
\end{tabular}

The binding score was obtained from the BIMAS program (https://www-bimas.cit.nih.gov/molbio/hla_bind/).

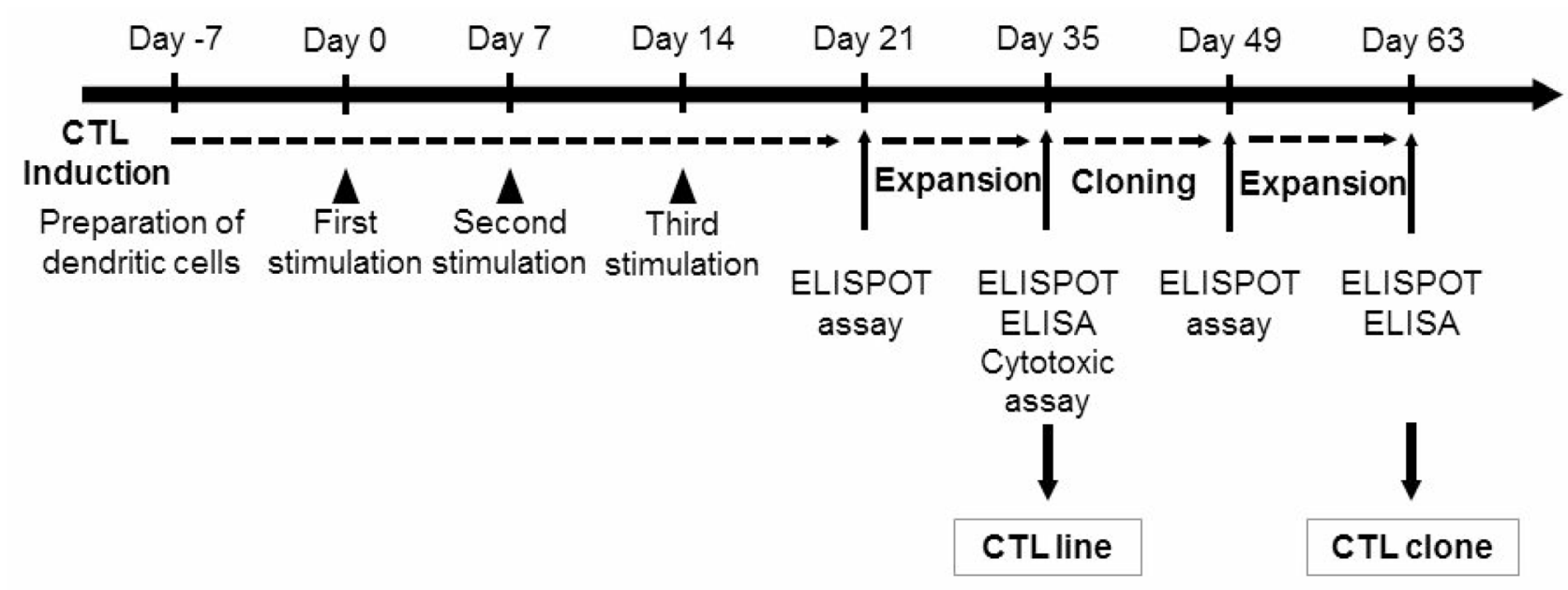

Figure 1: The protocol used for the identification of peptide-specific CTLs. CTLs were induced by a three-time stimulation with DCs loaded with mesothelin-derived peptides. Then, CTLs were examined for specificity for each peptide using IFN- $\gamma$ ELISPOT assays. Peptide-specific CTLs obtained from ELISPOT-positive wells were expanded and then examined with an IFN- $\gamma$ ELISPOT assay and ELISA and cytotoxic assay. Peptide-specific CTL clones were established using the limiting dilution method and examined using an IFN- $\gamma$ ELISPOT assay and ELISA. 


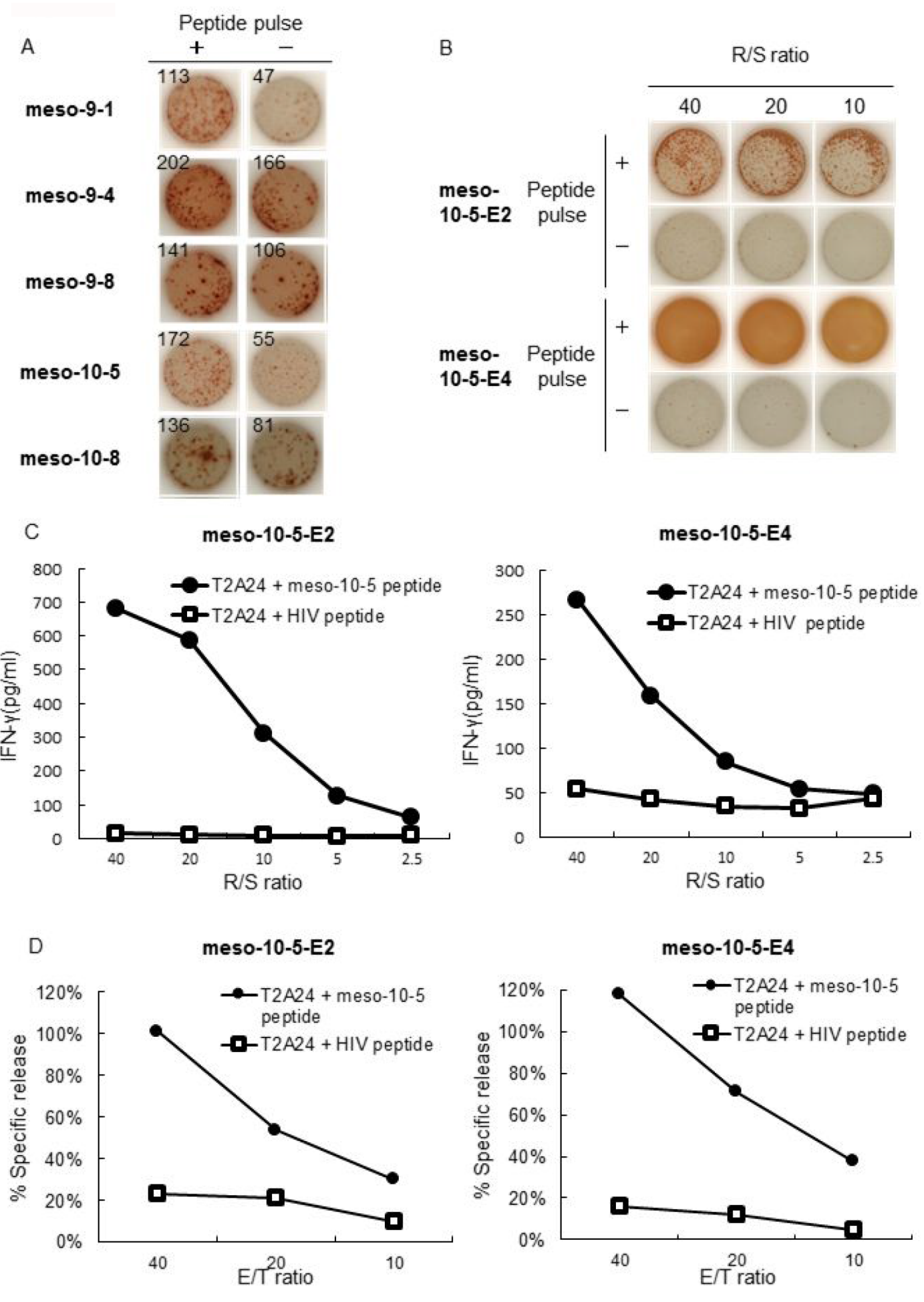

Figure 2: IFN- $\gamma$ production and cytotoxic activity of peptide-specific CTLs. (A) CTLs induced by mesothelin-derived peptides were stimulated with T2A24 cells pulsed with or without mesothelin-derived peptides. IFN- $\gamma$ production by CTLs in response to the meso9-1, meso-9-4, meso-9-8, meso-10-5, or meso-10-8 peptides was examined using an IFN- $\gamma$ ELISPOT assay. The numbers indicate the IFN- $\gamma$ ELISPOT counts per well. (B) IFN- $\gamma$ production by CTL lines induced with meso-10-5 peptide stimulation after CTL-expanding culture was examined with an IFN- $\gamma$ ELISPOT assay. R/S ratio, responder/stimulator ratio. (C) Meso-10-5 peptide-specific CTL line activity was examined with an IFN- $\gamma$ ELISA. R/S ratio, responder/stimulator ratio. (D) The cytotoxic activity of the mesothelin-10-5 peptide-specific CTL lines was examined with a fluorescence-based cytotoxicity assay. E/T ratio, effector/target ratio. 
specific CTL clones produced more IFN- $\gamma$ against HLA$\mathrm{A}^{*} 2402$-positive and mesothelin-expressing cell lines (KP2, KP3, and SUIT2 cells) than cell lines lacking either HLA-A*2402 or mesothelin (ASPC1, PANC1, and KP4 cells) (Figure 4B).

\section{Assessment of therapeutic efficacy of peptide- specific CTLs in vivo}

We investigated whether peptide-specific CTL treatment promotes pancreatic cancer rejection in mice. Treatment with peptide-specific CTL showed SUIT2 tumor regression in NSG mice, whereas a progressive increase in tumor growth was observed in control groups $(p<0.05)$ (Figure 5).

\section{DISCUSSION}

In the current study, we identified a new mesothelinderived epitope peptide restricted to HLA-A*2402. We successfully induced peptide-specific CTL lines that exhibited peptide-specific IFN- $\gamma$ production and cytotoxicity against $\mathrm{T} 2 \mathrm{~A} 24$ cells pulsed with the mesothelin-10-5 peptide (AFYPGYLCSL). Furthermore, we were able to establish mesothelin peptide-specific CTL clones. The peptide-specific CTL clones also exhibited peptide-specific IFN- $\gamma$ production against HLA-A*2402positive pancreatic cancer cells that endogenously expressed mesothelin. These results suggest that targeting mesothelin could be a novel approach for developing cancer vaccines for pancreatic cancer.

Mesothelin has been shown to be overexpressed in many human cancers, including mesothelioma, ovarian cancer, pancreatic cancer, lung cancer, gastric cancer, and biliary cancer [12, 17-22]. Furthermore, high expression of mesothelin was correlated with poor prognosis in several human cancers [22-24], and in pancreatic cancer, the coexpression of MUC16 and mesothelin was reported to be an independent prognostic factor for poor prognosis [12]. However, the expression and biological functions of mesothelin in cancer progression remain poorly understood. Recent studies have revealed that mesothelin may play an important role in cancer survival/ proliferation, tumor progression, and drug resistance through the Wnt/NF-kB/PI3K/Akt signaling pathway $[14,16,25]$. Furthermore, recent studies have revealed that mesothelin is associated with the invasion and migration of pancreatic cancer cells $[12,26]$. Thus, mesothelin might

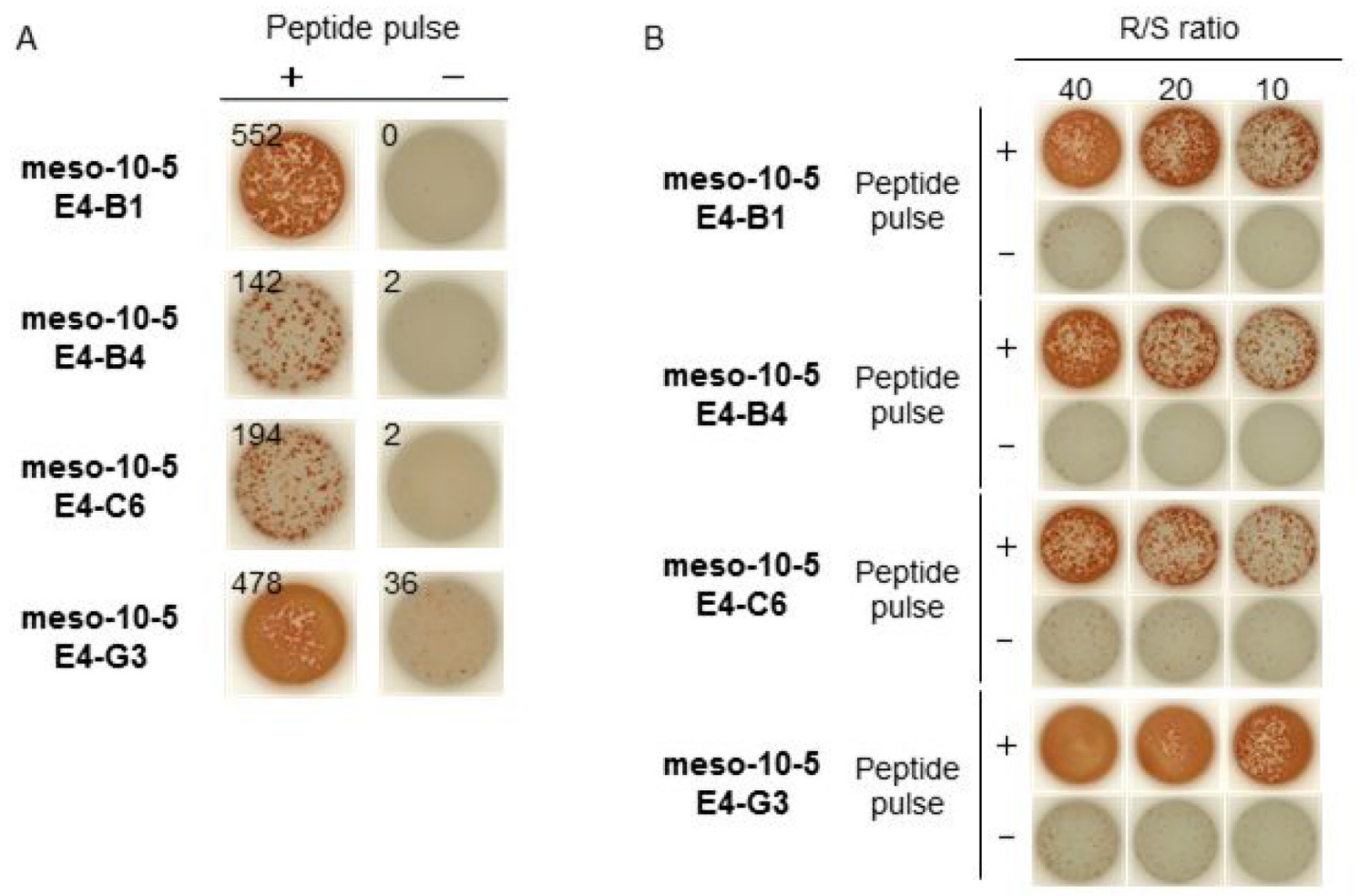

Figure 3: IFN- $\gamma$ production by meso-10-5 peptide-specific CTL clones. (A) Four established mesothelin-10-5 peptide-specific CTL clones were stimulated with T2A24 cells pulsed with or without meso-10-5 peptides. IFN- $\gamma$ production by CTL clones was examined using an IFN- $\gamma$ ELISPOT assay. The numbers indicate the IFN- $\gamma$ ELISPOT counts per well. (B) IFN- $\gamma$ production by CTL clones induced with meso-10-5 peptide stimulation after CTL clone expansion was examined with an IFN- $\gamma$ ELISPOT assay. R/S ratio, responder/ stimulator ratio. 
Table 2: Antigen expression in pancreatic cancer cell lines

\begin{tabular}{|c|c|c|}
\hline \multirow{2}{*}{ Pancreatic cancer cell lines } & \multicolumn{2}{|c|}{ Antigen expression } \\
\hline & mesothelin & HLA-A 2402 \\
\hline ASPC1 & + & - \\
\hline KP2 & + & + \\
\hline KP3 & + & + \\
\hline KP4 & - & + \\
\hline PANC1 & - & - \\
\hline SUIT2 & + & + \\
\hline
\end{tabular}

be an attractive therapeutic target for pancreatic cancer, and we focused on this protein for developing a cancer vaccine using an epitope peptide.

Several immunotherapy agents targeting mesothelin have been developed, and some trials have shown that targeting mesothelin is safe and does not result in toxicity to essential normal tissues [27, 28]. Mesothelin tumor vaccines are currently being evaluated, and their safety was established in a phase I clinical trial of patients with mesothelin-expressing advanced cancers, including pancreatic cancer [29]. In this study, we identified an HLA-A*2402-restricted novel epitope peptide derived from mesothelin. Our established epitope peptidespecific CTL clones responded to pancreatic cancer cells that endogenously expressed mesothelin in an HLAA24-restricted manner. These results suggest that the mesothelin-10-5 peptide (AFYPGYLCSL) is naturally processed from mesothelin in pancreatic cancer cells and

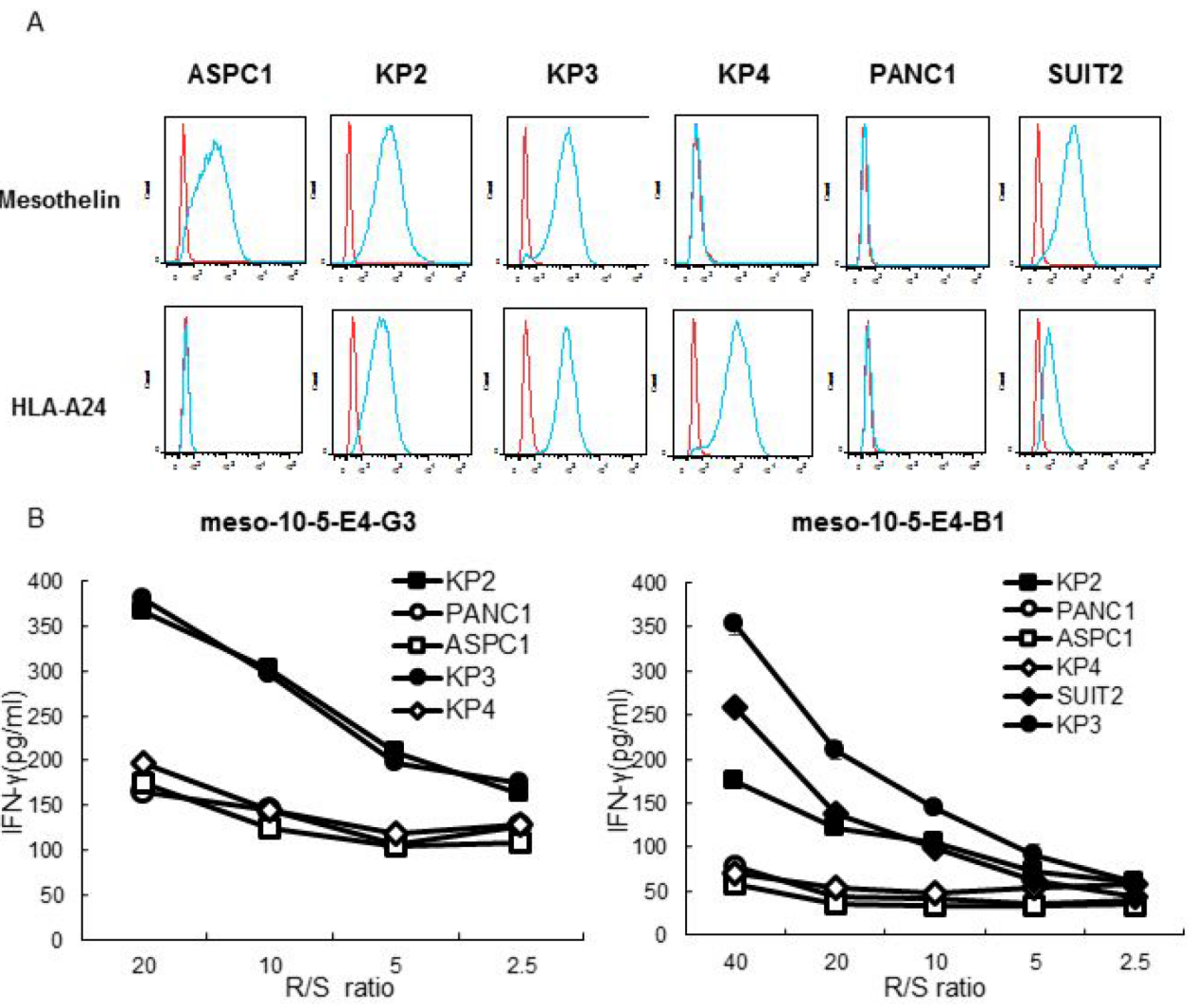

Figure 4: Peptide-specific CTL response to mesothelin and HLA-A*2402-expressing pancreatic cancer cells. (A) Flow cytometry analysis of the surface expression of mesothelin and HLA-A24 on human pancreatic cancer cell lines: ASPC1, KP2, KP3, KP4, PANC1, and SUIT2. Red line, isotype control. Blue line, mesothelin or HLA-A24 staining. Top row: using APC mouse anti-human isotype antibody and mouse anti-human mesothelin antibody. Bottom row: using PE mouse anti-human isotype antibody and PE mouse antihuman HLA-A24 antibody. (B) IFN- $\gamma$ production by mesothelin-10-5 peptide-specific CTL clones against pancreatic cancer cell lines was examined with an IFN- $\gamma$ ELISA. R/S ratio, responder/stimulator ratio. 
presented on the cell surface with the HLA-A24 molecule. Thus, mesothelin-10-5 peptide-specific CTLs might exert an antitumor effect against mesothelin-expressing pancreatic cancer cells in HLA-A24-positive patients.

Although cancer vaccines can induce an effective anti-tumor $\mathrm{T}$ cell response, a vaccine alone may be insufficient to induce a complete tumor cell-killing effect. An optimal anti-tumor immune response requires not only an increase in immune activation but also a decrease in immune suppression. The upregulation of PD-L1 has been reported in a wide variety of cancers, including pancreatic cancer, and the PD-1/PD-L1 pathway suppresses the antitumor immune response [30]. PD-L1 expression on a tumor can be induced thorough oncogenic pathways [31] or an adaptive immune resistance mechanism in response to the production of inflammatory cytokines by tumorinfiltrating lymphocytes [32-34]. Recent studies have reported that tumor-specific $\mathrm{T}$ cells were recruited to the tumor microenvironment and that immune checkpoint expression, including PD-L1, was upregulated in response to therapeutic vaccines in pancreatic cancer [9, 35]. Thus, the tumor microenvironment could be changed from a cold tumor to a hot tumor by a cancer vaccine. To overcome this cold tumor problem in which an antitumor effect is not achieved with a checkpoint inhibitor alone, a cancer vaccine to induce CTLs combined with checkpoint blockade antibodies that inhibit immune suppression represents a good combination therapy to mediate complete tumor suppression [36].

In addition to using vaccine-based therapies, other approaches such as $\mathrm{T}$ cell transfer therapies are also under consideration for immunotherapy. Chimeric antigen receptor $\mathrm{T}$ cells (CAR-T cells) are produced by one method for adoptive $\mathrm{T}$ cell transfer, and a preliminary study showed that mesothelin-specific CAR mRNAengineered $\mathrm{T}$ cells could induce an anti-tumor immune response [37]. A recent study has shown that checkpoint inhibitors could also enhance the CAR-T cell response [38]. These data suggest that mesothelin is a good target for cancer immunotherapy. Peptide vaccines have several advantages, including that peptide synthesis can be performed easily at a low cost and that their relative safety has been demonstrated in preclinical and clinical studies. Therefore, peptide cancer vaccines may be a good option for use in combination therapies.

In conclusion, we identified a novel HLA-A24restricted epitope peptide derived from mesothelin. Mesothelin is a promising target for peptide-based immunotherapy for patients with pancreatic cancer. Furthermore, a mesothelin peptide vaccine might be useful in future combination therapies with checkpoint inhibitors. Further investigations of the safety and efficacy of a mesothelin peptide vaccine are needed before clinical application.

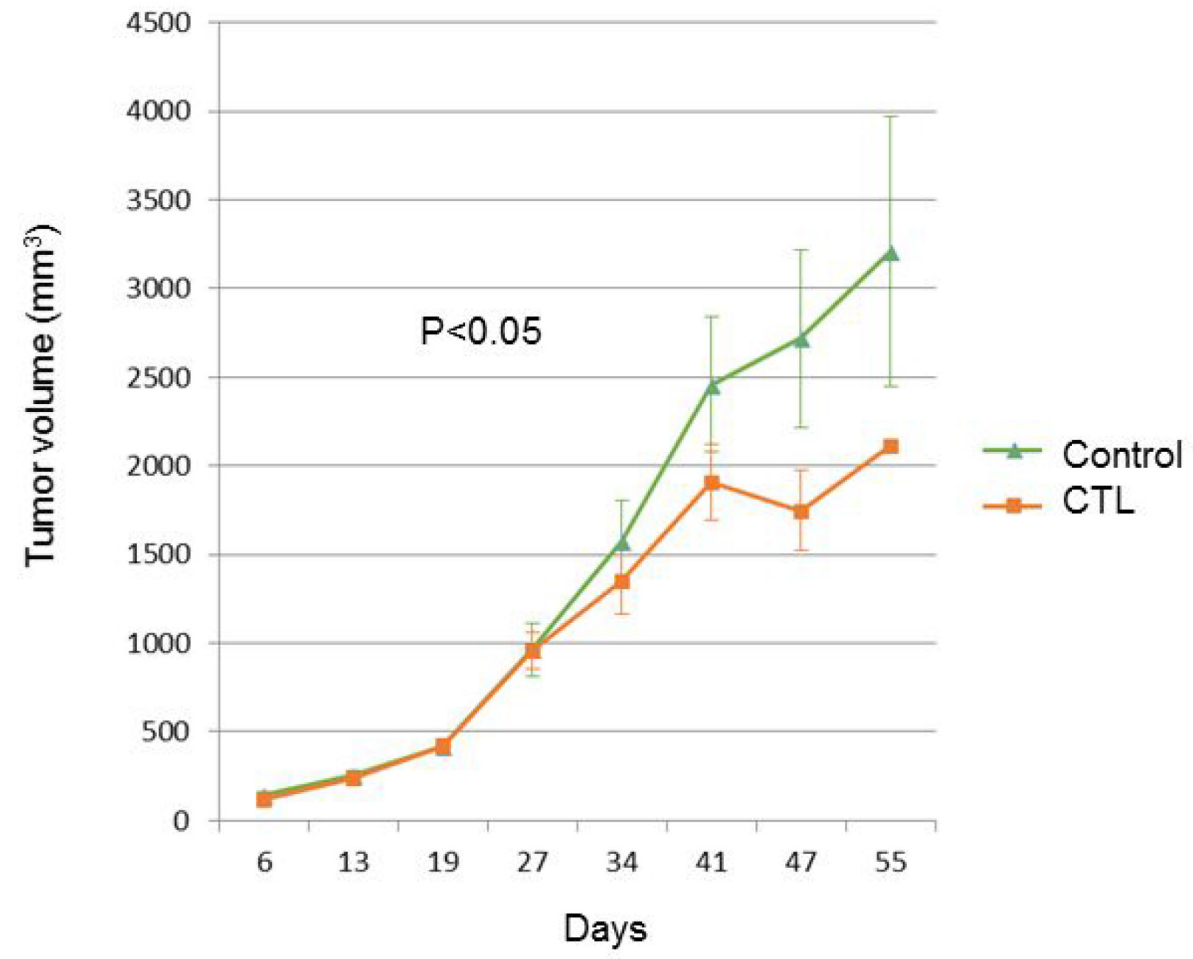

Figure 5: The tumor growth curve of SUIT2-xenograft tumors with or without mesothelin-specific CTL injection. 


\section{MATERIALS AND METHODS}

\section{Peptides}

Mesothelin-derived 9-mer and 10-mer peptides with high binding affinity to HLA-A:"24:02 were predicted with the binding prediction software "BIMAS" (http:// www-bimas.cit.nih.gov/molbio/hla_bind). HLA-A*24:02restricted HIV-derived epitope peptide (RYLKDQQLL) was used for a negative control, and HLA-A24 restricted CMV peptide (QYDPVAALF) was used for a positive control. Peptides were dissolved in dimethylsulfoxide at $20 \mathrm{mg} / \mathrm{ml}$ and stored at $-80^{\circ} \mathrm{C}$.

\section{Cell lines}

T2A24 (HLA-A*02:01, HLA-A*24:02, lymphoblast) cells were provided by Dr. Kuzushima (Aichi Cancer Center) [39]. Jiyoye (HLA-A32, B17, Bw37, Burkitt's lymphoma), EB-3 (HLA-A3, Aw32, Cw2, Burkitt's lymphoma), PANC-1 (pancreatic cancer), and ASPC1 (pancreatic cancer) cells were purchased from the American Type Culture Collection (Manassas, VA). T2A24 cells were maintained in RPMI1640 media with HEPES (Thermo Fisher Scientific, Waltham, MA) supplemented with $10 \%$ heat-inactivated fetal bovine serum (FBS; Biowest, France) and $0.8 \mathrm{mg} / \mathrm{ml} \mathrm{Geneticin}{ }^{\circledR}$ Selective Antibiotic (Thermo Fisher Scientific, Waltham, MA). Jiyoye and EB-3 cells were maintained in RPMI1640 media (Thermo Fisher Scientific, Waltham, MA) supplemented with $10 \%$ heat-inactivated FBS and $1 \%$ penicillin-streptomycin (liquid, Thermo Fisher Scientific, Waltham, MA). KP2, KP3, KP4, and SUIT2 cells were purchased from the JCRB Cell Bank (Japan). The expression levels of HLA-A 2402 and mesothelin were examined by flow cytometry with an antiHLA-A 2402 monoclonal antibody and anti-mesothelin antibody to select HLA-A*2402- and mesothelin-positive target cancer cells.

\section{In vitro induction of peptide-specific CTLs}

Peptide-specific CTLs were induced as described previously $[40,41] . \mathrm{CD}^{+} \mathrm{T}$ cells and dendritic cells (DCs) were prepared from peripheral blood mononuclear cells (PBMCs) obtained from HLA-A*24:02-positive healthy volunteers after receiving their written informed consent. This study was approval by an appropriate ethics committee, and all clinical procedures involving human subjects followed the principles expressed in the Declaration of Helsinki. PBMCs were isolated with Ficoll-Paque PLUS (GE Healthcare, Uppsala, Sweden) and separated into $\mathrm{CD} 8^{+} \mathrm{T}$ cell and $\mathrm{CD} 8^{-}$cell populations with a human CD8+ T Cell Isolation Kit (Miltenyi Biotec K.K., Japan). The monocyte-enriched CD8 ${ }^{-}$cell population was cultured in AIM-V medium (Invitrogen) containing 2\% heat-inactivated autologous serum (AS). After an overnight incubation, nonadherent cells were washed out, and 1,000 U/ml granulocyte-macrophage colony-stimulating factor (GM-CSF; R\&D Systems, Minneapolis, MN) and 1,000 U/ml interleukin (IL)4 (R\&D Systems) were added to the culture to induce monocyte-derived DCs. On day 4, $0.1 \mathrm{KE} / \mathrm{ml} \mathrm{OK}-432$ (Chugai Pharmaceutical Co., Tokyo, Japan) was added to the culture to induce the maturation of DCs. On day 7 , DCs were pulsed with $20 \mu \mathrm{g} / \mathrm{ml}$ the respective synthesized peptides in AIM-V medium containing $3 \mu \mathrm{g} / \mathrm{ml} \beta 2-$ microglobulin (Sigma-Aldrich, ST. Louis, MO) at $37^{\circ} \mathrm{C}$ for $3 \mathrm{~h}$.

These peptide-pulsed DCs were then incubated in media containing $30 \mu \mathrm{g} / \mathrm{ml}$ mitomycin C (MMC) (Kyowa Hakko Kirin Co. Ltd., Tokyo, Japan) at $37^{\circ} \mathrm{C}$ for $30 \mathrm{~min}$. After washing out the residual peptides and MMC, DCs were cultured with autologous $\mathrm{CD} 8^{+} \mathrm{T}$ cells on 48 well plates (Corning, Inc., Corning, NY) (each well contained $1.5 \times 10^{4}$ peptide-pulsed DCs, $3 \times 10^{5} \mathrm{CD}^{+} \mathrm{T}$ cells, and $10 \mathrm{ng} / \mathrm{ml} \mathrm{IL-7} \mathrm{(R \& D} \mathrm{Systems)} \mathrm{in} 0.5 \mathrm{ml}$ of AIM-V/2\% AS). Two days later, human IL-2 (Pepro Tech, Rocky Hill, NJ, USA) was added to the culture (final concentration: $20 \mathrm{IU} / \mathrm{ml}$ ). On days 14 and $21, \mathrm{~T}$ cells were further re-stimulated with the autologous peptide-pulsed DCs, which were freshly prepared each time. On day 28, interferon- $\gamma($ IFN- $\gamma$ ) production was examined by IFN- $\gamma$ enzyme-linked immunospot (ELISPOT) assay under stimulation with peptide-pulsed T2A24 cells.

\section{IFN- $\gamma$ enzyme-linked immunospot (ELISPOT) assay}

Peptide-specific CTL responses were investigated using an ELISPOT assay with an IFN- $\gamma$ ELISPOT kit and AEC substrate set (BD Biosciences, San Jose, CA) according to the manufacturer's instructions. For use as the stimulator cells, T2A24 cells were pulsed with $20 \mu \mathrm{g} / \mathrm{ml}$ the respective peptide at $37^{\circ} \mathrm{C}$ for $20 \mathrm{~h}$, and residual peptide that did not bind to cells was washed out. After removing $500 \mu \mathrm{l}$ of supernatant from each well of the induced peptide-specific CTLs, $100 \mu 1$ of cell culture suspensions was harvested from each well and co-cultured with stimulator cells $\left(1 \times 10^{4}\right.$ cells/well $)$ on an ELISPOT plate at $37^{\circ} \mathrm{C}$ for $20 \mathrm{~h}$. The resulting spots were counted using an ELIPHOTO Counter (Minerva Tech K.K., Japan).

\section{CTL expansion culture}

Peptide-specific CTLs obtained from ELISPOTpositive wells after in vitro CTL induction were expanded as described previously [42, 43]. Suspensions of the remaining peptide-specific CTLs were co-cultured with $5 \times 10^{6}$ MMC-treated $\left(30 \mu \mathrm{g} / \mathrm{ml}\right.$ at $37^{\circ} \mathrm{C}$ for $\left.30 \mathrm{~min}\right)$ Jiyoye and EB-3 cells in $25 \mathrm{ml}$ of $5 \%$ Auto serum/AIM-V containing $40 \mathrm{ng} / \mathrm{ml}$ anti-CD3 monoclonal antibody (BD 
Pharmingen, San Diego, CA) on day 0. IL-2 was added (final concentration: $120 \mathrm{IU} / \mathrm{ml}$ ) on day 1 , and $5 \%$ Auto serum/AIM-V containing $30 \mathrm{IU} / \mathrm{ml} \mathrm{IL-2}$ was provided on days 5, 8, and 11 . On day 14, expanded CTL activity was examined using an IFN- $\gamma$ ELISPOT assay.

\section{Establishment of peptide-specific CTL clones}

Peptide-specific CTL clones were established by the limiting dilution method. CTLs were diluted to $0.3,1$, and 3 cells/well in 96-well round-bottom plates (Corning, Inc.) and co-cultured with $1 \times 10^{4}$ cells/well of MMC-treated (30 $\mu \mathrm{g} / \mathrm{ml}$ at $37^{\circ} \mathrm{C}$ for $30 \mathrm{~min}$ ) Jiyoye and EB-3 cells in $150 \mu \mathrm{l}$ of $5 \%$ Auto serum/AIM-V supplemented with $30 \mathrm{ng} / \mathrm{ml}$ anti-CD3 monoclonal antibody and 125IU/ml IL-2 on day 0 . On day 10 , IL-2 was added to each well (125 UI/ml). On day 14, IFN- $\gamma$ an ELISPOT assay was performed to measure the CTL activity of each clone.

\section{Cytotoxicity assay}

The cytotoxic activity of peptide-specific CTLs was examined using flow cytometry in a fluorescence-based cytotoxicity assay. In the flow cytometry analysis, both carboxyfluorescein diacetate succinimidyl ester (CFSE) and mesothelin peptide-pulsed cells were used as the target cells, and HIV peptide-pulsed and CFSE-labeled cells were used as controls. Target and control cells were labeled with $10 \mu \mathrm{M}$ CFSE for $5 \mathrm{~min}$ each and co-incubated with CTL in $200 \mu \mathrm{l} /$ well of $5 \%$ AS/AIM-V on a $96-w e l l$ round-bottom plate for $4 \mathrm{~h}$. Cell culture suspensions were harvested and analyzed using a FACS-Canto II flow cytometer (Becton Dickinson, San Jose, CA).

Fluorescence-based cytotoxicity assays were carried out with DELFIA EuTDA Cytotoxicity Assay Reagents (PerkinElmer Life and Analytical Sciences, Boston, MA). Mesothelin peptide-pulsed cells and HIV peptidepulsed cells were used as the target cells and labeled with DELFIA BATDA reagent according to the manufacturer's instructions for $30 \mathrm{~min}$ at $37^{\circ} \mathrm{C}$. Then, the target cells with BATDA were incubated with peptide-specific CTLs for 4 h. After incubation, the supernatants were collected, and the time-resolved fluorescence was measured. Specific release was calculated as follows:

$\%$ Specific release $=[($ Experimental release Spontaneous release)/(Maximum release - Spontaneous release) $] \times 100$.

\section{IFN- $\gamma$ enzyme-linked immunosorbent assay (ELISA)}

The CTL activity was examined using an IFN- $\gamma$ ELISA. Peptide-pulsed cells $\left(1 \times 10^{4}\right.$ cells/well $)$ or pancreatic cancer cells $\left(5 \times 10^{4}\right.$ cells/well $)$ were used as a stimulator. CTLs were co-cultured with stimulator cells in $200 \mu \mathrm{l} /$ well of $5 \% \mathrm{AS} / \mathrm{AIM}-\mathrm{V}$ on 96 -well round bottom plates for $20 \mathrm{~h}$. After incubation, cell-free supernatants were collected, and IFN- $\gamma$ production was measured using a Human IFN- $\gamma$ ELISA set (BD Biosciences) and BD OptEIA $^{\text {TM }}$ Reagent Set B (BD Biosciences) according to the manufacturer's instructions.

\section{In vivo treatment}

Therapeutic effects of mesothelin peptide-specific CTLs were investigated in vivo in pancreatic cancer experiments. Six- to 8-week-old NOD/SCID common $\gamma$-chain knockout (NSG) female mice (Charles River) were used. In total, $10^{7}$ SUIT2 cells were subcutaneously implanted in the flanks of NSG mice; these cells expressed HLA-A2402 and mesothelin (Day 0). On days 23 and 37, mice received an intra-venous injection of $5 \times 10^{6}$ mesothelin-specific HLA-A2402 restricted CTLs. The untreated mice were injected with PBS as negative controls. Mice were weighed and tumor size was measured once a week.

\section{Author contributions}

Conception and design: M. Tsukagoshi, S. Wada, S. Hirono, T. Shirabe, H. Kuwano, and H. Yamaue; Development of methodology: S. Wada, S. Hirono, and H. Yamaue; Acquisition of data: M. Tsukagoshi, S. Wada, S. Yoshida, E. Yada, and H. Yamaue; Analysis and interpretation of data: M. Tsukagoshi, S. Wada, S. Hirono, S. Yoshida, E. Yada, T. Sasada, and H. Yamaue; Writing, review, and/or revision of the manuscript: M. Tsukagoshi, S. Wada, K. Shirabe, H. Kuwano, and H. Yamaue; Administrative, technical, or material support: S. Hirono, S. Wada, H. Kuwano, H. Yamaue; Study supervision: S. Wada, K. Shirabe, H. Kuwano, and H. Yamaue; All authors have read and approved the final manuscript.

\section{CONFLICTS OF INTEREST}

The authors have no conflicts of interest to disclose.

\section{REFERENCES}

1. Siegel RL, Miller KD, Jemal A. Cancer Statistics, 2017. CA Cancer J Clin. 2017; 67:7-30.

2. Ilic M, Ilic I. Epidemiology of pancreatic cancer. World J Gastroenterol. 2016; 22:9694-9705.

3. Moon HJ, An JY, Heo JS, Choi SH, Joh JW, Kim YI. Predicting survival after surgical resection for pancreatic ductal adenocarcinoma. Pancreas. 2006; 32:37-43.

4. Foley K, Kim V, Jaffee E, Zheng L. Current progress in immunotherapy for pancreatic cancer. Cancer Lett. 2016; 381:244-251.

5. Kleponis J, Skelton R, Zheng L. Fueling the engine and releasing the break: combinational therapy of cancer 
vaccines and immune checkpoint inhibitors. Cancer Biol Med. 2015; 12:201-208.

6. Royal RE, Levy C, Turner K, Mathur A, Hughes M, Kammula US, Sherry RM, Topalian SL, Yang JC, Lowy I, Rosenberg SA. Phase 2 trial of single agent Ipilimumab (anti-CTLA-4) for locally advanced or metastatic pancreatic adenocarcinoma. J Immunother. 2010; 33:828-833.

7. Brahmer JR, Tykodi SS, Chow LQ, Hwu WJ, Topalian SL, Hwu P, Drake CG, Camacho LH, Kauh J, Odunsi K, Pitot HC, Hamid O, Bhatia S, et al. Safety and activity of anti-PD-L1 antibody in patients with advanced cancer. N Engl J Med. 2012; 366:2455-65.

8. Antonia SJ, Larkin J, Ascierto PA. Immuno-oncology combinations: a review of clinical experience and future prospects. Clin Cancer Res. 2014; 20:6258-6268.

9. Soares KC, Rucki AA, Wu AA, Olino K, Xiao Q, Chai Y, Wamwea A, Bigelow E, Lutz E, Liu L, Yao S, Anders RA, Laheru D, et al. PD-1/PD-L1 blockade together with vaccine therapy facilitates effector T-cell infiltration into pancreatic tumors. J Immunother. 2015; 38:1-11.

10. Bardeesy N, DePinho RA. Pancreatic cancer biology and genetics. Nat Rev Cancer. 2002; 2:897-909.

11. Keleg S, Buchler P, Ludwig R, Buchler MW, Friess H. Invasion and metastasis in pancreatic cancer. Mol Cancer. 2003; $2: 14$.

12. Shimizu A, Hirono S, Tani M, Kawai M, Okada K, Miyazawa M, Kitahata Y, Nakamura Y, Noda T, Yokoyama S, Yamaue H. Coexpression of MUC16 and mesothelin is related to the invasion process in pancreatic ductal adenocarcinoma. Cancer Sci. 2012; 103:739-46.

13. Rump A, Morikawa Y, Tanaka M, Minami S, Umesaki N, Takeuchi M, Miyajima A. Binding of ovarian cancer antigen CA125/MUC16 to mesothelin mediates cell adhesion. J Biol Chem. 2004; 279:9190-98.

14. Bharadwaj U, Li M, Chen C, Yao Q. Mesothelin-induced pancreatic cancer cell proliferation involves alteration of cyclin E via activation of signal transducer and activator of transcription protein 3. Mol Cancer Res. 2008; 6:1755-1765.

15. Li M, Bharadwaj U, Zhang R, Zhang S, Mu H, Fisher WE, Brunicardi FC, Chen C, Yao Q. Mesothelin is a malignant factor and therapeutic vaccine target for pancreatic cancer. Mol Cancer Ther. 2008; 7:286-96.

16. Chang MC, Chen CA, Hsieh CY, Lee CN, Su YN, Hu YH, Cheng WF. Mesothelin inhibits paclitaxel-induced apoptosis through the PI3K pathway. Biochem J. 2009; 424:449-58.

17. Argani P, Iacobuzio-Donahue C, Ryu B, Rosty C, Goggins M, Wilentz RE, Murugesan SR, Leach SD, Jaffee E, Yeo CJ, Cameron JL, Kern SE, Hruban RH. Mesothelin is overexpressed in the vast majority of ductal adenocarcinomas of the pancreas: identification of a new pancreatic cancer marker by serial analysis of gene expression (SAGE). Clin Cancer Res. 2001; 7:3862-68.
18. Hassan R, Kreitman RJ, Pastan I, Willingham MC. Localization of mesothelin in epithelial ovarian cancer. Appl Immunohistochem Mol Morphol. 2005; 13:243-247.

19. Ordonez NG. Application of mesothelin immunostaining in tumor diagnosis. Am J Surg Pathol. 2003; 27:1418-1428.

20. Ordonez NG. Value of mesothelin immunostaining in the diagnosis of mesothelioma. Mod Pathol. 2003; 16:192-197.

21. Zheng C, Jia W, Tang Y, Zhao H, Jiang Y, Sun S. Mesothelin regulates growth and apoptosis in pancreatic cancer cells through p53-dependent and -independent signal pathway. J Exp Clin Cancer Res. 2012; 31: 84.

22. Kachala SS, Bograd AJ, Villena-Vargas J, Suzuki K, Servais EL, Kadota K, Chou J, Sima CS, Vertes E, Rusch VW, Travis WD, Sadelain M, Adusumilli PS. Mesothelin overexpression is a marker of tumor aggressiveness and is associated with reduced recurrence-free and overall survival in early-stage lung adenocarcinoma. Clin Cancer Res. 2014; 20:1020-28.

23. Hassan R, Thomas A, Alewine C, Le DT, Jaffee EM, Pastan I. Mesothelin Immunotherapy for Cancer: Ready for Prime Time. J Clin Oncol. 2016; 34:4171-4179.

24. Einama T, Kamachi H, Nishihara H, Homma S, Kanno H, Takahashi K, Sasaki A, Tahara M, Okada K, Muraoka S, Kamiyama T, Matsuno Y, Ozaki M, Todo S. Co-expression of mesothelin and CA125 correlates with unfavorable patient outcome in pancreatic ductal adenocarcinoma. Pancreas. 2011; 40:1276-82.

25. Prieve MG, Moon RT. Stromelysin-1 and mesothelin are differentially regulated by Wnt-5a and Wnt-1 in C57mg mouse mammary epithelial cells. BMC Dev Biol. 2003; 3:2.

26. Hassan R, Laszik ZG, Lerner M, Raffeld M, Postier $\mathrm{R}$, Brackett D. Mesothelin is overexpressed in pancreaticobiliary adenocarcinomas but not in normal pancreas and chronic pancreatitis. Am J Clin Pathol. 2005; 124:838-845.

27. Pastan I, Hassan R. Discovery of mesothelin and exploiting it as a target for immunotherapy. Cancer Res. 2014; 74:2907-2912.

28. Tang Z, Qian M, Ho M. The role of mesothelin in tumor progression and targeted therapy. Anticancer Agents Med Chem. 2013; 13:276-280.

29. Le DT, Brockstedt DG, Nir-Paz R, Hampl J, Mathur S, Nemunaitis J, Sterman DH, Hassan R, Lutz E, Moyer B, Giedlin M, Louis JL, Sugar EA, et al. A live-attenuated Listeria vaccine (ANZ-100) and a live-attenuated Listeria vaccine expressing mesothelin (CRS-207) for advanced cancers: phase I studies of safety and immune induction. Clin Cancer Res. 2012; 18:858-68.

30. Nomi T, Sho M, Akahori $T$, Hamada K, Kubo A, Kanehiro H, Nakamura S, Enomoto K, Yagita H, Azuma M, Nakajima Y. Clinical significance and therapeutic potential of the programmed death-1 ligand/programmed death-1 pathway in human pancreatic cancer. Clin Cancer Res. 2007; 13:2151-57. 
31. Atefi M, Avramis E, Lassen A, Wong DJ, Robert L, Foulad D, Cerniglia M, Titz B, Chodon T, Graeber TG, Comin-Anduix B, Ribas A. Effects of MAPK and PI3K pathways on PD-L1 expression in melanoma. Clin Cancer Res. 2014; 20:3446-57.

32. Spranger S, Spaapen RM, Zha Y, Williams J, Meng Y, Ha TT, Gajewski TF. Up-regulation of PD-L1, IDO, and $\mathrm{T}$ (regs) in the melanoma tumor microenvironment is driven by CD8(+) T cells. Sci Transl Med. 2013; 5:200ra116.

33. Taube JM, Anders RA, Young GD, Xu H, Sharma R, McMiller TL, Chen S, Klein AP, Pardoll DM, Topalian SL, Chen L. Colocalization of inflammatory response with B7-h1 expression in human melanocytic lesions supports an adaptive resistance mechanism of immune escape. Sci Transl Med. 2012; 4:127ra37.

34. Pardoll DM. The blockade of immune checkpoints in cancer immunotherapy. Nat Rev Cancer. 2012; 12:252-264.

35. Lutz ER, Wu AA, Bigelow E, Sharma R, Mo G, Soares K, Solt S, Dorman A, Wamwea A, Yager A, Laheru D, Wolfgang CL, Wang J, et al. Immunotherapy converts nonimmunogenic pancreatic tumors into immunogenic foci of immune regulation. Cancer Immunol Res. 2014; 2:616-31.

36. Ali OA, Lewin SA, Dranoff G, Mooney DJ. Vaccines combined with immune checkpoint antibodies promote cytotoxic T-cell activity and tumor eradication. Cancer Immunol Res. 2016; 4:95-100.

37. Beatty GL, Haas AR, Maus MV, Torigian DA, Soulen MC, Plesa G, Chew A, Zhao Y, Levine BL, Albelda SM, Kalos M, June CH. Mesothelin-specific chimeric antigen receptor mRNA-engineered $\mathrm{T}$ cells induce anti-tumor activity in solid malignancies. Cancer Immunol Res. 2014; 2:112-20.
38. John LB, Devaud C, Duong CP, Yong CS, Beavis PA, Haynes NM, Chow MT, Smyth MJ, Kershaw MH, Darcy PK. Anti-PD-1 antibody therapy potently enhances the eradication of established tumors by gene-modified $\mathrm{T}$ cells. Clin Cancer Res. 2013; 19:5636-46.

39. Kuzushima K, Hayashi N, Kimura H, Tsurumi T. Efficient identification of HLA-A*2402-restricted cytomegalovirusspecific CD8(+) T-cell epitopes by a computer algorithm and an enzyme-linked immunospot assay. Blood. 2001; 98:187-281.

40. Wada S, Tsunoda T, Baba T, Primus FJ, Kuwano H, Shibuya M, Tahara H. Rationale for antiangiogenic cancer therapy with vaccination using epitope peptides derived from human vascular endothelial growth factor receptor 2 . Cancer Res. 2005; 65:4939-46.

41. Uchida N, Tsunoda T, Wada S, Furukawa Y, Nakamura Y, Tahara H. Ring finger protein 43 as a new target for cancer immunotherapy. Clin Cancer Res. 2004; 10:8577-8586.

42. Osawa R, Tsunoda $\mathrm{T}$, Yoshimura $\mathrm{S}$, Watanabe $\mathrm{T}$, Miyazawa M, Tani M, Takeda K, Nakagawa H, Nakamura Y, Yamaue H. Identification of HLA-A24restricted novel $\mathrm{T}$ Cell epitope peptides derived from P-cadherin and kinesin family member 20A. J Biomed Biotechnol. 2012; 2012:848042.

43. Yoshimura S, Tsunoda T, Osawa R, Harada M, Watanabe T, Hikichi T, Katsuda M, Miyazawa M, Tani M, Iwahashi M, Takeda K, Katagiri T, Nakamura Y, Yamaue H. Identification of an HLA-A2-restricted epitope peptide derived from hypoxia-inducible protein 2 (HIG2). PLoS One. 2014; 9:e85267. 